\title{
O princípio da proteção ao salário sob a ótica dos direitos fundamentais
}

\author{
The principle of protecting the salary from the \\ perspective of the fundamental rights
}

\author{
Cristhian Magnus de Marco* \\ Gerson Luiz Carlos Branco**
}

\section{Resumo}

O salário e a aposentadoria dos segurados do Instituto Nacional do Seguro Social foram transformados em garantias especiais de obrigações contraídas diante de instituições financeiras a partir das leis $n^{\circ} 10.820$, de 17 de dezembro de 2003, e $n^{\circ} 10.953$, de 27 de setembro de 2004. Elas permitiram ao credor reter o objeto da garantia. A justificativa dessa inovação legal vincula-se ao fortalecimento do sistema financeiro por meio da redução do spread bancário - elevado pelo inadimplemento em larga escala - e da consequente facilitação do crédito para pessoas que dispõem somente do fluxo futuro de seu salário ou aposentaria para oferecer como garantia. Esse fenômeno é o objeto do presente artigo, cujo objetivo é investigar, por um lado, se a instituição de tal garantia é compatível com os direitos fundamentais, em especial a proteção ao salário, e, por outro, se existe possibilidade no ordenamento jurídico brasileiro de o credor apropriar-se do objeto da garantia. Já se adianta, como conclusão, que a transferência do produto da atividade do trabalhador como garantia do pagamento de uma dívida implica perda do poder de disposição do assalariado sobre a sua força de trabalho futura, que é sua principal fonte de manutenção, razão pela qual se defende o argumento de que a livre disposição do salário, necessária à autonomia da pessoa, tem a força de nulificar uma

* Doutor em Direito pela Pontifícia Universidade Católica do Rio Grande do Sul - PUC/RS, professor e pesquisador de Direito Constitucional-Civil na Universidade do Oeste de Santa Catarina UNOESC. Joacaba - RS - Brasil. Email: cristhian.demarco@unoesc.edu.br

** Doutor em Direito pela Universidade Federal do Rio Grande do Sul- UFRGS, professor e pesquisador de Direito Civil e Direito Empresarial na UFRGS e na Universidade do Oeste de Santa Catarina - UNOESC. Joacaba - RS - Brasil. 
cláusula que estabelecesse a irrevogabilidade da autorização do desconto em folha. Sublinha-se, também, que a jurisprudência brasileira não reconhece a possibilidade de apropriação direta de bens por parte do credor, em face do direito fundamental ao devido processo legal como exigência prévia à privação da liberdade ou dos bens de uma pessoa. Quanto à metodologia, trata-se de uma pesquisa bibliográfica e jurisprudencial, com a finalidade de buscar: aclaramentos conceituais, identificação de normas válidas e ponderações sobre a problemática proposta.

Palavras-chave: Liberdade contratual. Direitos fundamentais. Garantia das obrigações. Salário.

\section{Abstract}

The salary and retirement pension given by InstitutoNacional do Seguro Social were established as special warranty of obligation contracted with finantial institutions by laws 10.820, Dezember 17th 2003, and 10.953, September $27^{\text {th }}, 2004$, which also allowed the creditor to retain the warranty's object. The reason for this new creation is the strengthening of finantial system, enable through reduction of spread - affected by brech of contract in large scale - and the resulting facilitation of credit for those who only have their future salary or retirement pension to offer as awarranty. This article aims to investigate if the establishment of this warranty is consistent with fundamental rights - in particular, salary protection - and if the creditor's appropriation of the warranty's object is possible or not in brazilian law. In conclusion, it was found that transfering the product of a worker's activity as a payment warranty of a debt implies that he loses his power of disposition on his own future workforce, which is his main source of maintenance. In addition, the free disposition of salary, connected to individual autonomy, nullifies the clause that establishes the irrevocability of the authorization to retain the salary to pay the debt. Also, the creditor's appropriation of property is not recognized by courts, due to the fundamental right that requires due process of law before any deprivation of someone's freedom or property. Regarding methodology, it is literature and documents research, for the purpose of seeking: conceptual clearing, identification of valid norms and the presentation of judgments about the problematic proposal.

Keywords: Contractual freedom. Fundamental rights. Warrantyobligations. Salary. 


\section{Introdução}

Este artigo é o resultado de pesquisas sobre as perspectivas de caráter civil-constitucional concernentes à Lei $n^{\circ} 10.820$, de 17 de dezembro de $2003^{1}$. Esta e, posteriormente, a Lei $n^{0} 10.953$, de 27 de setembro de 2004, criaram uma garantia especial para as instituições financeiras: o salário dos trabalhadores e a aposentadoria pelo INSS, pois a autorização de desconto em folha passa a ser intangível e irretratável. Essas leis, editadas como uma espécie de reação às reiteradas decisões dos Tribunais autorizando o cancelamento do desconto em folha de pagamento por ato unilateral dos empregados, passaram a dar garantia de recebimento aos bancos.

É necessária, porém, a análise dessa garantia não apenas para explicitar a sua razão de ser conjuntural, mas em perspectiva esclarecida pelos princípios constitucionais protetores do salário e afins ${ }^{2}$, assim como das regras disciplinadoras de garantia das obrigações civis.

Essa análise mostra-se efetivamente imperativa, em razão da tensão existente entre a lei e as disposições constitucionais, assim como pelo "grau hierárquico mais elevado da Constituição, por um lado, e a autonomia do Direito Privado, por outro" (CANARIS, 2006, p. 207).

\footnotetext{
"Art. 10. Os empregados regidos pela Consolidação das Leis do Trabalho - CLT, aprovada pelo Decreto-Lei no 5.452, de 1 o de maio de 1943, poderão autorizar, de forma irrevogável e irretratável, o desconto em folha de pagamento dos valores referentes ao pagamento de empréstimos, financiamentos e operações de arrendamento mercantil concedidos por instituições financeiras e sociedades de arrendamento mercantil, quando previsto nos respectivos contratos". Esta Lei foi alterada pela Lei $\mathrm{n}$. 10.953, de 27 de setembro de 2004, para permitir que os aposentados vinculados ao INSS também fiquem autorizados a dar em garantia os seus benefícios: "Art. 60 . Os titulares de benefícios de aposentadoria e pensão do Regime Geral de Previdência Social poderão autorizar o Instituto Nacional do Seguro Social - INSS a proceder aos descontos referidos no art. 10 desta Lei, bem como autorizar, de forma irrevogável e irretratável, que a instituição financeira na qual recebam seus benefícios retenha, para fins de amortização, valores referentes ao pagamento mensal de empréstimos, financiamentos e operações de arrendamento mercantil por ela concedidos, quando previstos em contrato, nas condições estabelecidas em regulamento, observadas as normas editadas pelo INSS".

2 Visando a criação de uma expressão síntese abrangente, que possa ser utilizada para se referir à proteção salarial em sentido amplo, nossa sugestão é a categoria "princípio da proteção ao salário e afins", referindo-se, com isso, aos ganhos de trabalhadores públicos e privados, ativos e inativos, civis e militares.
} 
Dessa forma, para enfrentar o tema anunciado e cumprir com os objetivos propostos, a metodologia empregada cuidou, inicialmente, da contextualização dos institutos em análise, para depois, com amparo tanto na jurisprudência como na doutrina especializada sobre o assunto, apresentar algumas ponderações acerca do problema.

\section{Conceitos preliminares e contextualização da problemática}

A garantia é um dos elementos da obrigação, consistente na responsabilização patrimonial do devedor. Sua eficácia jurídica submete integralmente o seu patrimônio às ações do credor para realização de seu crédito. Como é limitada, no Direito vigente, a possibilidade de a garantia recair sobre a liberdade humana (sendo exceção a possibilidade da prisão de quem deve alimentos), cabe ao credor exercitar a sua garantia contra o patrimônio do devedor ${ }^{3}$.

Não obstante a totalidade do patrimônio do devedor responder por suas dívidas, segundo a regra estabelecida pelo art. 391 do Código $\mathrm{Civil}^{4}$, o legislador instituiu uma série de exceções para evitar que a execução das dívidas civis conduzisse à destruição econômica do devedor, levando em conta as consequências nefastas, sob o ponto de vista social, advindas de tal medida.

Assim, considera-se ser em demasia gravosa a penhora das ferramentas de trabalho do devedor para pagamento de dívidas civis, pois, ainda que não tenha outros bens, a limitação da possibilidade do exercício de uma atividade profissional provoca a redução da capacidade futura de geração de renda, inclusive para pagamento do débito, assim como das obrigações que possui com sua família, por exemplo. Da mesma maneira, o constituinte considerou direito fundamental a impenhorabilidade da propriedade rural quando os

A respeito da evolução do conceito de garantia e a evolução histórica e atual do regime no Direito Comparado, ver Leitão (2008). Sobre garantia das obrigações, conferir: Varela (2000), Galgano (1999), Oppo (1999), Cordeiro (1980), Larenz (1959) e Betti (1969).

"Art. 391. Pelo inadimplemento das obrigações respondem todos os bens do devedor." 
débitos forem provenientes do desenvolvimento de sua atividade produtiva ${ }^{5}$, sinalizando com clareza a extremada valorização - inclusive transindividual - conferida ao trabalho humano como fonte de sustento.

As regras a respeito da impenhorabilidade não protegem o devedor da insolvência, afinal, é insolvente, também, aquele que somente possui bens impenhoráveis ${ }^{6}$. A finalidade de tais regras é proteger a sociedade, pois, em razão da assistência incumbente ao Estado aos insolventes, a realização de um crédito - quando sua forma é demasiadamente onerosa ao próprio devedor - pode, ao fim e ao cabo, resultar no repasse dos custos para a sociedade: alguém que não possui recursos suficientes para pagar suas dívidas e tem o bem em que reside com sua família expropriado provavelmente acabará nas filas da assistência social, quando não sob as pontes de nossas metrópoles.

Essas razões de caráter social criam uma dualidade no patrimônio do devedor ${ }^{7}$, pois parte desse patrimônio não responde pelas dívidas civis - com as devidas exceções, como a relacionada no art. $3^{\circ}$, da Lei $n^{\circ} 8.009$, de 29 de março de 1990, que permite a penhora da residência familiar para garantir o pagamento dos débitos com os empregados domésticos, condomínio, impostos sobre o imóvel, fiança em contrato de locação (STF/RE 608.558), dentre outros.

A razão desse privilégio aos locadores teve como ratio a necessidade que "o mercado imobiliário" sinalizava (quando editada a Lei $n^{\circ} 8.245$, de 18 de outubro de 1991) para fomentar a locação,

5 "Art. $5^{\circ}$ da Constituição Federal: [...] XXVI - a pequena propriedade rural, assim definida em lei, desde que trabalhada pela família, não será objeto de penhora para pagamento de débitos decorrentes de sua atividade produtiva, dispondo a lei sobre os meios de financiar o seu desenvolvimento."

6 "Esclareça-se, desde já, que o conceito de insolvência acima é o do Direito Civil, pois a insolvência sob o ponto de vista do Direito Empresarial é a impontualidade, que prova a falta de liquidez, como se depreende do art. 94, I, da Lei n 11.101/2005."

7 Toma-se como excluído do "patrimônio" o conjunto de bens que são atributos da personalidade do devedor, ou seus direitos da personalidade, os quais, embora sejam bens, não se incorporam ao seu patrimônio, pois são indissociáveis da sua condição humana. Há direitos da personalidade, como o direito sobre a própria imagem ou os direitos autorais, que possuem estimação econômica. Embora o fundo do direito esteja vinculado à personalidade, os efeitos patrimoniais decorrentes dos contratos celebrados ou da exploração econômica são separáveis da pessoa e por isso passam a integrar o patrimônio. 
incentivando os proprietários de imóveis a disponibilizarem a propriedade imobiliária para locação, pois mais interessa à sociedade a circulação econômica, a ampliação da oferta e a redução geral dos preços da locação do que a proteção da residência do fiador ${ }^{8}$.

Em outras palavras, o imperativo social determinante do reforço da garantia a essa modalidade de crédito prende-se à existência de fatos econômicos que, sob o ponto de vista macroscópico, produzem um efeito benéfico para a sociedade, embora concretamente se esteja privilegiando a parte socialmente tida como a mais forte da relação, isto é, o locador, geralmente proprietário do bem locado.

Similar análise foi recentemente desenvolvida por Martins-Costa (2007), em artigo abordando o modelo dos juros no Direito brasileiro, justificando a necessidade de tratamento diferenciado das instituições financeiras ${ }^{9}$, de forma a compatibilizar a perspectiva macrojurídica (ou transindividual) e a microjurídica (ou interindividual) no exame de institutos e regras do Direito. A análise a partir de uma "perspectiva macrojurídica" leva em consideração os efeitos da regulamentação "na economia global da sociedade", relativizando uma visão baseada exclusivamente na justiça comutativa, adstrita às relações individuais e atomisticamente considerada.

Esse pressuposto é tomado em consideração tendo em vista que o Direito Privado não pode ser examinado em uma esfera limitada ao sujeito da relação jurídica atomisticamente considerada, seja por meio de uma análise meramente da estática relação crédito e débito, seja

8 A relação fiador/afiançado tem natureza privada e a proteção ao "patrimônio mínimo" sucumbe diante da contraposição posta pelo interesse social. Em outras palavras, a relação fiador/ afiançado protege um interesse privado, menos "importante" para o Estado do que o interesse social da circulação patrimonial.

9 "Evidencia-se então, o fato de o tratamento jurídico dos juros ter direta relação com o desenvolvimento do País, com o crescimento da sua atividade produtiva ou, contrariamente (se os juros são excessivamente altos), com o empobrecimento e com as dificuldades da atividade produtiva, pois é favorecida a especulação, e a roda da 'ciranda financeira' se põe a girar em detrimento da produção. Subjacente a perspectiva macrojurídica está a ideia de justiça distributiva. Admite-se que o Direito Privado não se esgota nas relações privadas intersubjetivas, mas mantém relações diretas e reflexas com a comunidade, lócus de atuação dos interesses meta individuais ou transubjetivos." (MARTINS-COSTA, 2007, p. 241-245). 
porque a relação obrigacional, quando vista como totalidade dinâmica, não pode ser dissociada dos seus fins. E os fins não são unicamente determinados pelo vínculo obrigacional, mas, igualmente, pelos valores consubstanciados na norma jurídica estruturante do respectivo sistema jurídico.

\section{Do salário como garantia de obrigações bancárias}

Anteriormente, assinalou-se ter sido constituída a nova garantia às instituições financeiras, em razão da necessidade do mercado de reduzir o spread bancário. Como se sabe, o inadimplemento constituise um elemento de extrema relevância, com o objetivo final de reduzir o preço do crédito para aqueles que não possuem bens e contam apenas com o seu salário ou aposentadoria.

Essas pessoas acabavam ficando à margem do sistema de concessão de crédito, por não terem garantias patrimoniais e, muitas vezes, pela existência de restrições cadastrais. Com a edição da Lei, foram integradas no mercado do crédito, pois passaram a contar com um bem extremamente valioso, qual seja, o seu fluxo financeiro futuro, derivado do salário ou da aposentadoria, para oferecer em garantia.

O aumento nas possibilidades de concessão do crédito anda, porém, de braços dados com o fortalecimento do sistema financeiro. Esse fortalecimento tem por razão de ser a circunstância de os bancos e as instituições financeiras, de modo geral, não emprestarem seu capital próprio, mas os recursos advindos da poupança popular. Em outras palavras, "o segmento econômico bancário funciona basicamente como um intermediário entre os poupadores e os tomadores de empréstimo" (THEODORO JÚNIOR, 2013).

Nessa perspectiva macrojurídica, a doutrina tem considerado que a responsabilidade econômica pelas altas taxas de juros praticadas pelo sistema financeiro é fundamentalmente provocada pela alta inadimplência e demora no processo de recuperação judicial dos créditos (THEODORO JÚNIOR, 2013). A análise dos dados fornecidos pelo 
Banco Central do Brasil sobre o perfil do spread bancário médio indica que, na década passada, o custo com a inadimplência representava 35\% do spread bancário. Cem por cento do provisionamento das instituições financeiras são revertidos para elevação das taxas de juros praticadas para determinado produto financeiro (CARDOSO, 2002) ${ }^{10}$.

Nessa linha, é importante a observação feita pelo Ministro João Noronha, do STJ, a respeito da fragilidade do sistema de garantias existentes no Direito brasileiro. Conforme sua manifestação no XII Congresso Internacional de Direito Comparado, o sistema de garantias deveria ser "reescrito". Nesse sentido, a Lei n 10.953, de 27 de setembro de 2004, foi de extrema importância para fornecer ao sistema financeiro uma garantia consistente sobre os benefícios de aposentadoria e pensão. A jurisprudência parece andar na mesma linha e tem considerado que, embora deva ser limitado o desconto ao máximo de $30 \%$ dos vencimentos, tal garantia é válida, propiciando, inclusive, "a obtenção de taxas de juros inferiores às regularmente aplicadas"11.

Porém, como já se assinalou, conquanto festejada pelo sistema financeiro e por aqueles que têm sede de crédito, tal garantia precisa ser examinada sob a ótica do texto constitucional, para que se verifique sua compatibilidade com o sistema de proteção dos direitos fundamentais. É possível sustentar a total intangibilidade do salário por força do mandamento constitucional dos artigos $1^{\circ}$, III, e $7^{\circ}, \mathrm{X}$, da Constituição Federal $^{12}$, dispositivos que instituem o princípio adotado expressamente

10 "High taxation levels and the costs of non-performing loans also affect bank spreads between interest rates on deposits and interest rates on loans." (CARDOSO, 2002, p. 2).

11 "O procedimento com a intervenção de entidades associativas visa a facilitar a obtenção dos bens de consumo, revelando-se os descontos em folha uma forma de garantia contratual a fim de propiciar, inclusive, a obtenção de taxas de juros inferiores às regularmente aplicadas, muitas vezes. Posição firmada da Câmara. A alegação de impenhorabilidade do salário não prospera, pois não se trata de penhora e sim de cumprimento de um contrato mediante o pagamento voluntário da obrigação. Recurso Provido." (Agravo de Instrumento № 70010678142, Vigésima Câmara Cível, Tribunal de Justiça do RS, Relator: Léo Romi Pilau Júnior, Julgado em 25/05/2005).

12 "Art. $1^{\circ}$ A República Federativa do Brasil, formada pela união indissolúvel dos Estados e Municípios e do Distrito Federal, constitui-se em Estado Democrático de Direito e tem como fundamentos: [...] III - a dignidade da pessoa humana. Art. $7^{\circ}$ São direitos dos trabalhadores urbanos e rurais, além de outros que visem à melhoria de sua condição social: [...] X - proteção do salário na forma da lei, constituindo crime sua retenção dolosa". 
no art. 649, IV, do Código de Processo Civil ${ }^{13}$. Questiona-se, ademais, se essa matéria deve ou não ser objeto de lei complementar, tendo em vista o disposto no art. 192 da Constituição Federal (OLIVEIRA, 2006) ${ }^{14}$.

É bem verdade que o constituinte tratou da irredutibilidade do salário, assim como da proteção do salário na forma da lei, constituindo crime sua retenção dolosa, mas não dispôs de forma expressa regra similar à do art. 649, IV, do Código de Processo Civil. Essa circunstância, porém, não afasta a impenhorabilidade do salário e a inserção de tal norma no elenco dos direitos fundamentais do cidadão, já que a disposição do Código de Processo Civil nada mais faz do que estabelecer uma proteção ao salário, por estar associado de maneira direta e inafastável à força de trabalho.

A força de trabalho do assalariado (e, a partir de certo tempo, a aposentadoria, istoé, o repousoligado normativamenteao desgaste dessa mesma força) não pode ser considerada riqueza ou bem desprendido da natureza e da condição humana, pois a sua percepção tem origem em uma atividade básica ligada ao animal laborans, correspondente ao processo biológico do corpo e às suas necessidades básicas, na sua luta constante para consumir, repousar e, assim, sobreviver.

Adota-se, a propósito, a distinção proposta por Arendt (1981) entre o labor e o trabalho: o labor ${ }^{15}$ é a atividade que se esgota em si mesma, nada remanescendo após a sua realização; já o trabalho é a atividade humana produtora de coisas e da reificação que elas significam.

13 "Art. 649. São absolutamente impenhoráveis: IV - os vencimentos, subsídios, soldos, salários, remunerações, proventos de aposentadoria, pensões, pecúlios e montepios; as quantias recebidas por liberalidade de terceiro e destinadas ao sustento do devedor e sua família, os ganhos de trabalhador autônomo e os honorários de profissional liberal, observado o disposto no § 30 deste artigo;" (Redação dada pela Lei n 11.382, de 2006).

$14 \mathrm{O}$ art. 192 tem a seguinte redação, determinada pela Emenda Constitucional n. 40/2003: "Art. 192. O sistema financeiro nacional, estruturado de forma a promover o desenvolvimento equilibrado do País e a servir aos interesses da coletividade, em todas as partes que o compõem, abrangendo as cooperativas de crédito, será regulado por leis complementares que disporão, inclusive, sobre a participação do capital estrangeiro nas instituições que o integram."

15 "Os produtos do labor, produtos do metabolismo do homem com a natureza, não duram no mundo o tempo suficiente para se tornarem parte dele, e a própria atividade do labor, concentrada exclusivamente na vida e em sua manutenção, é tão indiferente ao mundo que é como se este não existisse." (ARENDT, 1981, p. 130). 
Mesmo que o assalariado esteja vinculado a uma atividade com uma carga mais densa de reificação, as coisas por ele produzidas e o conhecimento acumulado que impregna as coisas fabricadas podem garantir a cultura e a memória sobre o que o homem foi no passado. Não garantem, porém, a apropriação de tais coisas. É preciso o salário para manter a vida, pois o trabalho, para o assalariado, não é uma contingência, mas uma necessidade (ARENDT, 1981) ${ }^{16}$.

Com base nessa distinção, chega-se à conclusão de que o assalariado, ainda que não represente mais o conceito de operário do século XIX ou do início do século XX, continua tendo como seu principal bem a força de trabalho, e o salário como fruto que lhe permite consumir e sobreviver.

Em síntese: as condições que peculiarizam o trabalho humano afastam a possibilidade jurídica de se transferir o produto de sua atividade futura como garantia absoluta do pagamento de uma dívida sem atentar contra a própria condição humana: a existência biológica é condição inafastável do exercício do trabalho. Para o aposentado, essa condição se reproduz na medida em que se considera - fática e juridicamente - já não haver possibilidades de alienação da força de trabalho, remanescendo, todavia, como consequência da atividade exercida, o direito à percepção de proventos para manutenção da existência, conforme regulado pelo sistema de distribuição de riscos e de previdência social organizado pelo Estado.

Essas considerações permitem compreender a razão pela qual, em certas circunstâncias, a condição biológica não permite que o salário seja recebido ou impõe a necessidade de uso do salário para manutenção de sua vida biológica e integridade física. Trata-se de uma razão moderna, aguçada muito recentemente pela proeminência dos direitos de personalidade como categoria jurídica central. A referência

16 Segundo Arendt (1981, p. 169) o homo faber, que realiza trabalho e não mero labor, tem no mercado o lugar das trocas, transformando tudo em mercadoria, mediante uma instrumentalização que "implica em rebaixar todas as coisas à categoria de meios e acarreta a perda do seu valor intrínseco e independente." 
de Arendt (1981, p. 133), segundo a qual "nas condições da escravidão, os poderosos da terra podiam usar até mesmo os seus sentidos através de terceiros, podiam ver e ouvir através de seus escravos", indica o grau de instrumentalidade a que é possível submeter o ser humano. Porém, esse caráter instrumental cede em um momento histórico no qual a escravidão é rejeitada e a autodeterminação passa a ser um valor fundamental de nossa ordem jurídica, exigindo que se compreenda a livre disposição do salário como uma necessidade para a manutenção da autonomia.

É nessa perspectiva que o constituinte instituiu o enunciado genérico de proteção ao salário, tendo em vista todas as circunstâncias que, de alguma maneira, retirem do trabalhador a sua fonte de manutenção, pois vincular o salário ao pagamento de obrigações específicas representa, em certa medida, "escravizar" o assalariado, pois o resultado do seu trabalho futuro não servirá para sua manutenção, mas para pagamento de uma dívida.

Assentada a perspectiva geral, a questão é saber até que ponto as razões do legislador para instituir tal garantia em benefício das instituições financeiras seriam sustentáveis sob o prisma da disposição constitucional da proteção ao salário.

Embora a Constituição Federal não trate da impossibilidade de se dar em garantia do pagamento de uma dívida o salário (antes referindo a genérica fórmula proteção ao salário), a interpretação a ser feita não pode deixar de considerar o conjunto de normas que, além da irredutibilidade, da proibição à redução análoga à condição de escravo e da impenhorabilidade, são aptas a colorir com determinando significado o mencionado direito fundamental social.

Tomando-se os direitos fundamentais como normas que possuem âmbitos de proteção restringíveis por outros direitos fundamentais ou por interesses coletivos (ALEXY, 2008), observa-se não ser adequado simplesmente deixar de aplicar as disposições legais previstas na Lei $n^{\circ}$ 10.953/03 pela circunstância de não estar, prima faciei, em conformidade com um princípio que lhe é contrário. Para que se possa 
verificar a validade dessa regra, é preciso observar se os princípios que fundamentam as regras estão preservados e em até que medida essas regras são compatíveis com o sistema das garantias obrigacionais e os princípios que lhe informam. Isso se realiza por meio de ponderações.

\section{Da proteção ao salário e afins: as restrições ao autopagamento, a irrevogabilidade da autorização do desconto em folha e os limites da penhora}

A proteção ao salário não pode se dar pela proibição da penhora, pois o mecanismo criado pelas Leis $n^{\circ} 10.953 / 04$ (proventos e pensões), $n^{\circ} 10.820 / 03$ (salários) e Decreto n 6386/08 (remuneração de servidores públicos federais) outorga ao credor uma ação de direito material, permitindo a realização do crédito, independentemente da intervenção do Poder Judiciário. Ou seja, trata-se de uma hipótese nova no contexto do Direito Privado brasileiro, estabelecendo uma duplicidade de efeitos: o primeiro foi transformar o salário em garantia e o segundo foi permitir que o credor aproprie-se do objeto da garantia.

A compreensão da dupla eficácia é imprescindível para o enfrentamento da problemática envolvendo, em primeiro lugar, a compatibilidade da transformação do salário em garantia de obrigações perante instituições financeiras com a disposição do direito fundamental à proteção do salário e, por outro lado, se, no ordenamento jurídico pátrio, é possível que o credor fique com o objeto da garantia.

A lógica da criação dessa dupla eficácia está em um aspecto prático, que é a transformação da folha de pagamentos em "meio de pagamento", com o objetivo de facilitar o pagamento das dívidas. É de conhecimento público o baixo custo de implantação do desconto em folha de pagamento, pois facilita a atuação das instituições financeiras e contribui para a redução do spread bancário pela redução dos custos administrativos.

Esse aspecto prático também poderia ser considerado em outras situações, como no caso da hipoteca, do penhor ou da alienação 
fiduciária em garantia. Daí a pergunta: o sistema jurídico pátrio admite que o credor fique com o objeto da garantia? A resposta dada historicamente tanto pela doutrina quanto pela jurisprudência é negativa e também encontra fundamento constitucional.

\subsection{Aspectos histórico-jurisprudenciais sobre a impossibilidade de o credor apropriar-se diretamente do objeto da garantia}

São bastante conhecidas as decisões do STF (no período anterior a 1988) que deram origem à proibição do pacto comissório ilícito, por violação do princípio jurídico que estava insculpido no art. 765 do Código Civil de $1916^{17}$. Embora a jurisprudência brasileira admita que a compra e venda possa ser mista ou conter disposições que não sejam exatamente próprias da compra e venda, não se tem admitido que esta seja utilizada como instrumento para constituição de garantia de recebimento de determinada quantia emprestada. Também não há uma rejeição direta e expressa de autorização para realização de negócios jurídicos indiretos e fiduciários ${ }^{18}$, embora sua eficácia seja limitada ${ }^{19}$.

17 "Art. 765. É nula a cláusula que autoriza o credor pignoratício, anticrédito ou hipotecário a ficar com o objeto da garantia, se a dívida não for paga no vencimento."

18 A jurisprudência mais antiga do Supremo Tribunal Federal negava a possibilidade de negócios indiretos, principalmente pela forte doutrina de Eduardo Espínola, como se pode ver no Recurso Extraordinário n. 60.699/Guanabara, $2^{\mathrm{a}}$ Turma, Rel. Min. Aliomar Baleeiro, j. 08.11.1966, Audiência de publicação em 16.11.1967. A decisão considerou a matéria sob o ponto de vista da "utilidade": "Sem dúvida, um negócio fiduciário, como sustentam as doutas decisões de f., pode ser lícito para o fim pretendido pelas partes nestes autos, - o de garantir dívida periclitante da firma comercial de que era sócio o Recorrente varão. Lícito, mas inútil, porque há meios mais eficazes e adequados no Direito positivo do Brasil, para tal objetivo. Só não há é meio lícito de ficar o credor com o objeto da garantia se não for pago. Isso lhe não é permitido nem extensivamente, nem pela simulação duma cessão de direitos de promessa de venda, porque contraria princípio de ordem pública do artigo 765 do C.Civ. E então, segundo os melhores doutrinadores, como Eduardo Espínola, ou como Ferrara, citados pelas venerandas decisões, desaparece o negócio aparente para que prevaleça a realidade dissimulada e condenada pela lei, - no caso o citado artigo 765 do C.Civ." A visão do referido acórdão e a necessidade de proximidade do direito com a realidade é reconhecida no acórdão por menção à situação fática ainda presente na realidade brasileira: "O Sr. Ministro Aliomar Baleeiro: - Não sei se os eminentes Ministros notaram, nos jornais (o jornal 'é uma janela aberta sobre a vida'), que há sujeitos que anunciam: 'Empresto dinheiro sob hipoteca e também com pacto de retrovenda'. Pois bem, é muito comum simular-se a hipoteca num pacto de retrovenda, para maior desembaraço do credor. Se o devedor não paga, ele fica logo com o bem". No acórdão, embora tenha sido admitido o negócio fiduciário, não foram atribuídos os efeitos pretendidos pelas partes, mas somente os admitidos pelo ordenamento, no caso, foi declarada a impossibilidade do credor ficar com a propriedade do bem transferido em 
Desde a década de 1940, a jurisprudência tem proferido decisões em torno da regra do art. 765 do Código Civil de 1916, estendendo a eficácia de tal artigo para outros casos, convertendo tal regra em verdadeiro princípio jurídico do Direito Privado ${ }^{20}$. A transmutação da regra em princípio geral do Direito Privado tem por razão de ser a ratio da norma. O que essa regra visou tradicionalmente evitar foi a apropriação, pelo credor, do bem objeto da garantia sem a observação prévia de avaliação ou a obediência a princípios e garantias, como o devido processo legal e contraditório ${ }^{21}$. Construiu-se, assim, a ideia segundo a qual a ilicitude consistente na impossibilidade de o credor

garantia. Decisão em sentido contrário foi proferida no julgamento do Recurso Extraordinário n. 82.447, Rel. Min. Moreira Alves, que admite o negócio fiduciário salvo quando o "escopo" for fraudar lei imperativa. Ou seja, o "controle do escopo", mediante a confrontação da finalidade prevista pelo tipo jurídico e a finalidade a ser alcançada pelas partes, indica se o negócio é indireto e se busca fraudar lei imperativa. No referido acórdão, Moreira Alves admite a celebração do negócio fiduciário, tendo em vista que não foi visualizada a violação de lei imperativa, no caso a Lei da Usura.

19 A doutrina brasileira debate-se constantemente com esse problema, havendo muitos estudos sobre a possibilidade de negócios jurídicos fiduciários e indiretos, principalmente com o objetivo de admitir tipos contratuais do direito estrangeiro, que são incompatíveis com o sistema pátrio caso do trust ou de determinadas modalidades de garantia.

20 Importante observar, por lealdade ao leitor, que as ideias aqui apresentadas são polêmicas. Judith Martins-Costa sustenta que as razões da vedação ao pacto comissório "tem uma explicação histórica e teleológica. A finalidade da vedação é, tão-somente, obstar a possibilidade de vir a ser quebrado o sinalagma, pelo credor pignoratício, hipotecário ou anticrético, em desfavor do devedor. Se não existe essa possibilidade a vedação do pacto comissório é anacrônica e já era em Roma, quando 'criado o 'pacto marciano' (PONTES DE MIRANDA no Tratado de Direito Privado, Tomo XX, par. 2.422) [...] Além do mais, o próprio CC flexibiliza a rigidez da proibição do pacto. Conquanto tenha repetido, no caput do art. 1.428, a regra do art. 765 do Código revogado, o vigente Código Civil acrescentou-lhe um parágrafo único, permitindo ao devedor, após o vencimento da obrigação, dar em pagamento ao credor o bem hipotecado. Assim, é possível estipular que, para fins de execução da garantia, em caso de inadimplemento, haverá dação em pagamento". (MARTINS-COSTA, 2011, p. 160).

21 BRASIL. Superior Tribunal de Justiça, REsp n. 2216/SP, $3^{a}$ Turma, Rel. Nilson Naves, j. 28.05.1991, DJ. 01.07.1991, REsp 475.040/MG, 3a Turma, Rel. Min. Ari Pargendler, j. 24.06.2003, DJ. 13.10.2003, REsp 2216/SP). Para os fins deste estudo, deixa-se de fazer uma análise mais aprofundada de opiniões no sentido da irrelevância da função típica dos contratos, defendendo, por exemplo, ser possível a utilização da compra e venda como instrumento de garantia. "Se tomarmos como objeto de reflexão a compra e venda e se aceitarmos que ela se caracteriza pelo consenso em trocar uma coisa por certo preço, verificaremos que, em princípio, isto é, nas hipóteses normais, não há necessidade da distinção que fizemos, entre elemento categorial a integrar o objeto, e causa, definida, conforme geralmente se faz, como função prático-social do negócio, ou como função econômico-social, pois haverá total correspondência entre ambos. Todavia, nada impede que se use a compra e venda, já não mais com a finalidade de circulação de bens, mas como a função diversa, por exemplo, com escopo de garantia, como acontece 
ficar com o objeto da garantia não ser apenas um princípio, mas uma regra atrelada ao direito fundamental, previsto no art. $5^{\circ}$, LIV, segundo o qual ninguém será privado da liberdade ou de seus bens sem o devido processo legal: a tradição do Direito Privado brasileiro consagrou regra que é verdadeiro meio de eficácia de direitos fundamentais estruturantes do Estado Democrático de Direito.

A própria definição de garantia sob o ponto de vista do Direito das Obrigações estabelece como sendo da sua essência a coação estatal mediante as mais diferentes ações para cumprimento das obrigações civis, já que "não se pode contar para aquele efeito com a actuação directa do credor, atenta a proibição legal da auto-defesa" (VARELA, 2000, p. 129) 22 .

Essa afirmação de Varela caminha na trilha da tradição segundo a qual a possibilidade de o credor atingir o patrimônio do devedor depende sempre da mediação estatal. No mesmo sentido, embora sob outro ponto de vista, Galgano (1999) sustenta ser uma característica essencial das obrigações a sua estrita "patrimonialidade", o que torna a possibilidade de autopagamento pela retenção do salário em execução de cláusula contratual uma deformação dessa natureza, pois o salário não é um bem com conotação puramente patrimonial, carregando consigo elementos indissociáveis da pessoa, como a força de trabalho

na compra e venda com pacto de retrovenda. Aí muda a função, e se realmente fosse esta que determinasse diretamente o tipo do negócio e respectivo regime jurídico, estes também mudariam. Tal não ocorre, nem nesse caso (o negócio, ainda que a função seja outra, continua a ser compra e venda), nem em todas as outras hipóteses de negócio indireto, justamente porque é o elemento categorial inderrogável, e não a função, que fixa o tipo e o regime jurídico de cada negócio." (AZEVEDO, 2002, p. 148).

22 "Ora, não há dúvida de que tanto a acção (declarativa) destinada a exigir judicialmente o cumprimento da obrigação (e a consequente sentença de condenação do devedor), como a execução forçada, dão lugar a relações de carácter processual, em que figuram como sujeitos o autor (ou exequente), o réu (ou executado) e o Estado (representado pelos tribunais). Mas estas relações são o meio processual destinado a dar realização efectiva a um poder substantivo (pretensão) que integra a relação obrigacional, tal como a ação de reivindicação, por exemplo, se destina a dar execução a uma faculdade que brota diretamente do direito de propriedade." (VARELA, 2000, p. 130). 
necessária à sua manutenção. Fora do âmbito patrimonial, a cláusula contratual carece de validade e falta juridicidade ao vínculo obrigatório ${ }^{23}$.

$\mathrm{Na}$ doutrina portuguesa, Almeida Costa (2009, p. 153-154) estende o conceito de garantia das obrigações para considerar como tal "o conjunto de providências coercitivas que o direito predispõe para a tutela da posição do sujeito activo." Critica a doutrina clássica afirmando ser possível a adoção de medidas extrajudiciais de tutela, remetendo especificamente para a ação direta como meio de realização do direito e indicando como fundamento a disposição expressa do artigo 336 do Código Civil Português. Essa disposição tão conhecida ${ }^{24}$ traz consigo alguns elementos do sistema brasileiro, pois exige, entre outros requisitos, a indispensabilidade de recorrer em tempo útil aos meios coercitivos normais, condicionando sua licitude a uma cláusula geral da ponderação de bens. Não será, portanto, lícita quando sacrificar interesses superiores aos que o agente visa a realizar ou assegurar.

Por essa mesma razão, Almeida Costa (2009, p. 154), ao tratar da garantia como elemento da obrigação, menciona que "quanto aos direitos de crédito, tal elemento concretiza-se em certas medidas judiciárias facultadas ao credor para defesa do seu interesse", pois se o devedor não cumprir a obrigação, o credor pode agir "por intermédio dos tribunais" para atingir o patrimônio do devedor.

23 "Il carattere patrimoniale di questi diritti vale, da un lato, a distinguere il diritto reale da altri diritti che, come il diritto reale, sono diritti assoluti, cioè spettanti nei confronti di tutti, ma che difettano, tuttavia, del carattere della patrimonialità: sono i diritti della personalità, come il diritto alla vita, all'integrità fisica, al nome, all'onore, alla riservatezza e cosi via." Galgano (1999, p. 7).

24 "Artigo $336^{\circ}$ (Acção directa) 1. É lícito o recurso à força com o fim de realizar ou assegurar o próprio direito quando a acção directa for indispensável, pela impossibilidade de recorrer em tempo útil aos meios coercivos normais, para evitar a inutilização prática desse direito, contanto que o agente não exceda o que for necessário para evitar o prejuízo. 2. A acção directa pode consistir na apropriação, destruição ou deterioração de uma coisa, na eliminação da resistência irregularmente oposta ao exercício do direito, ou noutro acto análogo. 3. A acção directa não é lícita quando sacrifique interesses superiores aos que o agente visa realizar ou assegurar." 
3.2 Da apropriação do trabalho como garantia no ordenamento brasileiro vigente

No Direito brasileiro não se tem regra geral sobre a "ação direta", sendo a matéria regida pelo art. 591 e seguintes do Código de Processo Civil, que trata da responsabilidade patrimonial. As únicas hipóteses em que se admite a realização de direitos sem a mediação do Poder Judiciário estão vinculadas às excludentes de antijuridicidade, como o estado de necessidade e a legítima defesa. Outras hipóteses de ação direta que se poderia identificar são o desforço imediato, previsto no $\S 1^{\circ}$, do art. 1210 do Código Civil25, ou os embargos em ação de nunciação de obra nova, obedecidas as regras do art. 935 do Código de Processo Civil, que exige a ratificação judicial do embargo ${ }^{26}$.

Em ambos os casos, está-se diante de mecanismos de defesa do direito de propriedade ou da posse, um direito cuja estrutura permite atos de defesa de forma direta, pois sua violação pressupõe uma intervenção do sujeito passivo na esfera de proteção jurídica sob controle direto do sujeito ativo. É diferente nas relações de crédito, nas quais o sujeito ativo, para realizar o seu direito, precisa intervir na esfera alheia ${ }^{27}$.

Se há uma garantia "real", como resolver o problema da "indeterminação" e a circunstância de o salário poder existir ou não, considerando-se que, se o empregado ou servidor vier a deixar o emprego, a garantia desaparecerá? Essa circunstância, em vez de revelar que a garantia depende de ato do empregado, expõe uma circunstância mais grave, qual seja, a condição existencial do salário

25 "§ 10 O possuidor turbado, ou esbulhado, poderá manter-se ou restituir-se por sua própria força, contanto que o faça logo; os atos de defesa, ou de desforço, não podem ir além do indispensável à manutenção, ou restituição da posse."

26 "Art. 935. Ao prejudicado também é lícito, se o caso for urgente, fazer o embargo extrajudicial, notificando verbalmente, perante duas testemunhas, o proprietário ou, em sua falta, o construtor, para não continuar a obra. Parágrafo único. Dentro de 3 (três) dias requererá o nunciante a ratificação em juízo, sob pena de cessar o efeito do embargo."

27 De relevante interesse é o trabalho de Giorgio Oppo a propósito de garantias dadas no âmbito do sistema financeiro europeu quando de sua formação, para distinguir as garantias pessoais das garantias reais, assim como as garantias de valor das garantias pecuniárias, mediante a problematização feita em torno do antecedente do Euro (o ECU - ), cujo raciocínio e problemas lá tratados contribuem para a reflexão deste artigo. (OPPO, 1999, p. 525-555). 
para o trabalhador. Ainda que nos últimos anos o desemprego no Brasil seja menor do que historicamente foi, ele continua sendo uma ameaça ao trabalhador, e o posto de trabalho é condição para a garantia de condições mínimas para manutenção própria.

A circunstância de o devedor precisar do emprego para sobreviver é a garantia do credor nas obrigações constituídas sob o regime das Leis $n^{\circ} 10.820 / 2003$ e $n^{\circ} 10.953 / 2004$. A estabilidade do servidor público faz com que sua remuneração seja uma garantia ainda melhor, conforme o Decreto $n^{\circ} 6386 / 2008$, não sujeita ao risco da demissão imotivada.

Por outro lado, o "salário" não é patrimônio sob qualquer condição, seja civil, fiscal ou sob qualquer ponto de vista jurídico. Não é "pecúnia", embora deva ser pago em pecúnia, pois consiste em um "valor" vinculado à contraprestação pelo trabalho prestado. Assim, constituindo contraprestação vinculada a um contrato bilateral (contrato de trabalho), o que verdadeiramente é objeto da garantia é, em ultima instância, o trabalho a ser prestado, pois se não houver trabalho, o empregador não fica obrigado ao pagamento do salário.

Também é ínsito a toda garantia real o direito de prelação do devedor, o que, evidentemente, não teria sentido no caso, pois o exercício da garantia é um modo de realização do pagamento, e não de execução da obrigação.

Esse raciocínio demonstra que há uma garantia, mas ela é de natureza pessoal e recai sobre elementos não patrimoniais, no caso, o trabalho a ser prestado e os seus respectivos frutos consubstanciados no salário.

3.3 Do uso do salário, remuneração ou proventos como pagamento, garantia ou penhora e os riscos à dignidade humana

Cordeiro (1980, p. 157) estuda a exigência de patrimonialidade da garantia dedicando-se, ao versar a responsabilidade patrimonial, a examinar o "teor geral da coercibilidade no Direito das Obrigações". Pontua, por consequência, duas circunstâncias ou limites claros no Direito das Obrigações: a impossibilidade, nas obrigações, de fazer 
infungíveis e compelir o devedor a executar a prestação; e a proscrição da justiça privada, um topos tradicional da cultura jurídica, advindo da Lei das Doze Tábuas, em 450 a.C. Como expõe o autor, o regime previsto na Tábua III, que permitia a manusinjectio,

conduziu, no séc. IV a.C., a uma grave questão social, uma vez que a plebe, endividada, era, progressivamente, arrastada para a escravidão. As pressões, daí advenientes, levaram à aprovação da Lex Poetelia Papira de nexis, em 326 a.C., que, proibindo o se nexumdare, veio concitar os interessados a encontrar outras soluções negociadas. Foi abolida a escravidão e a morte do devedor, quando não fosse satisfeita a obrigação em falta. (CORDEIRO, 1980, p. 159)

Por essa razão, e como comprovado na sequência histórica mencionada por Cordeiro (1980, p. 160-161), os efeitos pessoais da execução foram "progressivamente atenuados" até ir-se "chegando à regra geral da responsabilidade patrimonial", norteada pela lógica de que "pelo cumprimento das obrigações respondem os bens do devedor e só. Nunca o próprio devedor.” (CORDEIRO, 1980, p. 164).

O patrimônio constitui, segundo o mesmo autor, "um complexo de direitos e obrigações, avaliáveis em dinheiro, que o Direito sujeita a um regime comum quanto à responsabilidade por dívidas." (CORDEIRO, 1980, p. 167). Em outras palavras, não se pode considerar juridicamente a capacidade de trabalho como "patrimônio", embora se saiba que, sociologicamente, na linha do pensamento marxista, o trabalho é considerado como a "mercadoria" detida pelos trabalhadores para trocar no mercado (MARX, 1993) 28 .

28 Deve-se observar que a crítica marxista se dá pela formação da mais-valia, pela geração de lucro produzida pelo trabalho. Marx sequer pensava na hipótese de que o próprio "salário" fosse retido em um processo de produção capitalista, pois tal prática era característica de modos de produção com características feudais ou escravagistas: "Dono e vendedor da força pessoal de trabalho, o trabalhador recebe com o nome de salário fração do produto na qual se corporifica a parte do trabalho, a qual chamamos de trabalho necessário, isto é, o trabalho necessário para manter e reproduzir essa força de trabalho, sejam as condições dessa manutenção e reprodução pobres ou ricas, favoráveis ou desfavoráveis". 
Considerações similares têm conduzido, em outros sistemas, à impossibilidade de o salário atuar como garantia das obrigações. Na Alemanha, Karl Larenz (1959) indica decisões dos Tribunais de 1940 e 1952, afirmando que tanto salários como soldos não podem ser objeto de constrição pelo credor para realizar sua pretensão, por servirem ao próprio sustento do devedor ${ }^{29}$. Com efeito, a evolução histórica mudou o "objeto" da intervenção do credor, afastando a objetivação da pessoa e objetivando a responsabilidade sobre o patrimônio do devedor. Nesse sentido, foi fundamental a separação dogmática entre "débito e responsabilidade", procedida por Brinz nos finais do séc. $\mathrm{XIX}^{30}$.

No Brasil, porém, como se viu, preferiu o legislador andar na contramão da tradição, aproveitando-se da inexistência de proibição expressa. Ainda assim, a lei não consegue fugir do conjunto de ferramentas institucionais, discursivas e comunicacionais construídas ao longo da história pela tradição ${ }^{31}$. E esta nos dá algumas normas

"Los salarios, sueldos, etc., que se considera inembargable por servir al propio sustento - para cumplir la pretensión del acreedor. Todo su patrimonio y sus ingresos quedan sujetos, prescidiendo de las excepciones citadas, a intervención por via ejecutiva. Decimos que el deudor 'responde' de su deuda con su patrimonio." (LARENZ, 1959, p. 32).

30 Além da própria obra de Larenz (1959), é importante para este trabalho a definição do vínculo obrigacional como relação completa integrada por dois elementos, o débito (Schuld) e a responsabilidade (Haftung). O débito consiste no dever de prestar, na necessidade de observância de um determinado comportamento (dar, fazer ou não fazer). A responsabilidade é a sujeição do patrimônio do devedor aos fins da execução. Varela (2010, p. 143-155). Emílio Betti (1969, p. 254) dedica-se exaustivamente sobre a mesma matéria em um capítulo de seu Direito das Obrigações, intitulado La responsabilidad considerada en si misma, no qual apresenta o conceito de responsabilidade, compreendida sua função de garantia "es aquella particular posición de una persona que resulta del destino jurídico de un bien que le perenence a servir de satisfacción a otra persona por un suceso que ésta espera o teme; destino independiente de la voluntad del titular del bien, e individualizado tanto respecto al mismo bien como respecto al suceso".

31 Ferramentas no sentido utilizado por Hespanha (1997, p. 26, 27): "a tradição não representa um resultado, um valor, uma norma; mas uma série de ferramentas [...] com as quais são produzidos novos resultados. Na verdade, o trabalho de produção de novos efeitos jurídicos (novas normas, novos valores, novos dogmas) é levado a cabo com ferramentas recebidas da tradição: ferramentas institucionais (instituições, papéis sociais), ferramentas discursivas (linguagem técnica, tópicos, modelos de argumentação e de prova, conceitos e dogmas), ferramentas comunicacionais (bibliotecas, redes acadêmicas ou intelectuais). É desta forma que o passado modela o presente. Não pela imposição directa de valores e de normas, mas pela disponibilização de uma grande parte da utensilagem social e intelectual com que se produzem novos valores e novas normas." 
inerentes ao sistema de proteção dos direitos civis antagônicos com as leis em comento: (1) direito à proteção ao salário; (2) proibição de o credor ficar com o objeto da garantia; (3) impenhorabilidade do salário; (4) garantia das obrigações deve ter natureza patrimonial e integrar o patrimônio do devedor.

Tais direitos estão vinculados diretamente aos princípios do devido processo legal, da proteção do salário e da autodeterminação. Por isso, é preciso contextualizar social e historicamente a possibilidade de o credor apropriar-se do objeto da garantia ou realizar um autopagamento e analisar as suas duas dimensões - estrutural e funcional. A dimensão estrutural evidencia a relação entre crédito e débito, com um caráter neutro em relação aos sujeitos. A dimensão funcional, por sua vez, estabelece uma vinculação entre essa relação e a sua origem, a sua causa, por isso, a partir da função prático-social a que corresponde, há a definição de direitos, obrigações e poderes do credor $^{32}$.

Os direitos fundamentais da proteção ao salário, do devido processo legal, do contraditório e da autodeterminação asseguram claramente não ser possível instituir um mecanismo pelo qual o devedor não tenha alternativa que não se subjugar aos interesses do credor, em prejuízo à sua dignidade.

\section{Casuística brasileira e a inconstitucionalidade da cláusula de irretratabilidade e irrevogabilidade da autorização para desconto/consignação em folha de pagamento}

Não se pode ignorar que o Brasil é um país com uma grande população de baixo poder aquisitivo, para a qual o salário é a principal

\footnotetext{
32 A busca da função está relacionada ao 'aspecto causativo': "Ela assume uma disciplina segundo a sua causa, a qual é expressão da sua disciplina: o aspecto funcional e aquele causativo exprimem a mesma exigência, isto é, individuar e completar uma relação entre situações subjetivas. 0 credor, segundo seja a causa uma ou outra, tem, ou não, determinados poderes, obrigações [...]" (PERLINGIERI, 2002, p. 117).
} 
(senão a única) fonte de renda, essencial para manutenção da saúde, alimentação, transporte e educação, direitos também previstos no mesmo texto constitucional e que o Estado brasileiro ainda não conseguiu suprir adequadamente, seja por meios diretos ou indiretos.

Ainda que extremamente respeitável, o argumento da necessidade de solidez do sistema financeiro nacional e de ampliação e reforço da eficácia das garantias em favor dos credores não pode chegar ao ponto de usar o único bem da população mais pobre, que é o salário, para tal fim. Embora propicie a socialização do crédito em um primeiro momento, logo a seguir propicia a transferência de renda das mãos dos mais pobres para os mais ricos.

Os mais ricos não são somente as instituições financeiras, mas aqueles que adquirem CDBs, CDIs, quotas de fundos de investimento e recebem os polpudos juros do sistema financeiro nacional. Estes, representativos da "poupança popular", precisam ser preservados, mas jamais os fins justificam meios que sacrifiquem valores e princípios superiores do ordenamento. Nesse sentido, não se podem sacrificar direitos fundamentais para fins econômicos de razão útil, mas que a médio e longo prazo contribuem para a concentração da renda e em curto prazo ferem princípios que integram o Estado Democrático de Direito.

Não se pode deixar de considerar, também, que a "guerra" das instituições financeiras e a ampliação do crédito encontraram limites nas classes média e alta, razão pela qual tem se ampliado o fenômeno da popularização do crédito, crescendo substancialmente o crédito de pequena monta, tal como o crédito para aquisição de alimentos, vestuário, telefones celulares, dentre outros.

Deixando de lado as considerações econômicas e jurídicopolíticas, não se está afirmando que é nula a autorização para desconto em folha, pois não se pode esquecer que o contrato que autoriza o desconto é celebrado sob a égide da autonomia privada, também um direito fundamental. 
Porém, o que viola os princípios e regras constitucionais mencionados é a situação fática segundo a qual o trabalhador, servidor, aposentado ou pensionista, necessitando de sua renda para a manutenção, não tem como promover o cancelamento do desconto em folha e vê a garantia ser executada automaticamente, sem qualquer escolha, sem obediência ao devido processo legal.

Em outras palavras, pode-se considerar que o desconto em folha como um "meio de pagamento" escolhido voluntariamente não é ilícito. Porém, deverá ser considerada nula a cláusula segundo a qual a autorização de desconto é irrevogável em relação às prestações vincendas.

A declaração unilateral do empregado para cancelar o desconto em folha é válida e eficaz, tendo em vista as normas constitucionais segundo as quais é assegurada a proteção ao salário, assim como é garantido que ninguém será privado de seus bens sem o devido processo legal. Ou seja, não há como realizar qualquer processo de expropriação ou bloqueio sem a concordância do devedor ou sem a intervenção do Poder Judiciário.

O ordenamento é expresso ao afastar a possibilidade de intervenção administrativa (ação direta) como asseguradora de créditos privados em favor de instituições financeiras contra as disposições constitucionais acima mencionadas.

Importante lembrar, por fim, que a Lei $n^{\circ} 11.382$, de 2006, ao modificar o Código de Processo Civil, em seu artigo 649, inciso IV, fez constar como absolutamente impenhoráveis os vencimentos, subsídios, soldos, salários, remunerações, proventos de aposentadoria, pensões, pecúlios e montepios. E ainda: as quantias recebidas por liberalidade de terceiro e destinadas ao sustento do devedor e sua família, os ganhos de trabalhador autônomo e os honorários de profissional liberal.

O texto aprovado pelo Congresso limitava a impenhorabilidade da renda em 20 salários mínimos, utilizando tal parâmetro como critério de proporcionalidade, deixando a entender que tudo o que ultrapassasse tal 
valor não poderia ser considerado essencial à manutenção de uma pessoa ou sua família ${ }^{33}$. Entrementes, essa limitação foi vetada, sob o argumento de que a tradição jurídica brasileira "é no sentido da impenhorabilidade absoluta e ilimitada de remuneração”. Mais um argumento, portanto, que corrobora para concluir-se pela inconstitucionalidade da previsão de irretratabilidade e irrevogabilidade da autorização para ação direta de obrigações.

\section{Conclusão}

Chega-se à conclusão de que o sistema de garantias deve ser preservado, mas não a qualquer custo. Assim como não se admite a prisão civil como garantia de dívidas, os princípios constitucionais estruturados sob a forma de direitos fundamentais que garantem o devido processo legal e a proteção do salário afastam a validade da regra que torna irrevogável a autorização para desconto em folha como forma de pagamento de obrigações contraídas no âmbito do sistema financeiro nacional.

Não há autorização da Constituição Federal para que o legislador conceda aos particulares o direito potestativo de se autopagar mediante o desconto em folha sem que se fira de morte os direitos fundamentais antes mencionados, já que não se trata simplesmente de "autorizar" o desconto ou consignação, mas de retirar, eventualmente, as condições

33 Razões do veto ao $\S 3^{\circ}$, do artigo 649, do CPC: "O Projeto de Lei quebra o dogma da impenhorabilidade absoluta de todas as verbas de natureza alimentar, ao mesmo tempo em que corrige discriminação contra os trabalhadores não empregados ao instituir impenhorabilidade dos ganhos de autônomos e de profissionais liberais. Na sistemática do Projeto de Lei, a impenhorabilidade é absoluta apenas até vinte salários mínimos líquidos. Acima desse valor, quarenta por cento poderá ser penhorado. A proposta parece razoável porque é difícil defender que um rendimento líquido de vinte vezes o salário mínimo vigente no País seja considerado como integralmente de natureza alimentar. Contudo, pode ser contraposto que a tradição jurídica brasileira é no sentido da impenhorabilidade, absoluta e ilimitada, de remuneração. Dentro desse quadro, entendeu-se pela conveniência de opor veto ao dispositivo para que a questão volte a ser debatida pela comunidade jurídica e pela sociedade em geral." 
para a preservação do mínimo existencial que dá dignidade ao ser humano ${ }^{34}$.

Pelo contrário, a autonomia privada concede o poder de os particulares autorregularem suas relações, dando-se regras. Vinculada ao poder geral de autodeterminação (liberdade da pessoa em decidir o seu destino, conforme suas preferências), a autonomia privada trata da liberdade de autovinculação, de constituição de relações jurídicas a partir de atos autônomos e não heterônomos ${ }^{35}$. Jamais a autonomia privada pode ser interpretada como instrumento para constituição de garantias que violem regras básicas do ordenamento constitucional que protegem a pessoa e atributos que lhe são caros, como é o caso do salário como fonte de manutenção de um mínimo existencial.

O princípio da autonomia privada, decorrente do art. $5^{\circ}, \mathrm{I}, \mathrm{XIII}$, XVII, e XXXVI e do art. 171 da Constituição Federal ${ }^{36}$ fica alijado, sendo suprimido pela possibilidade de autopagamento das instituições financeiras, pois a cada mês deve o assalariado ou o aposentado ter a liberdade de decidir o destino que vai dar à remuneração recebida naquele período, sendo absolutamente incoerente com nosso sistema constitucional a indisponibilidade futura de salário que ainda não foi adquirido.

34 Como diz Jorge Miranda (2006, p. 173-185), a regra constitucional da não discriminação impede que o legislador estabeleça discriminações entre concretos sujeitos econômicos como elemento essencial do Direito de Iniciativa.

35 Sobre a problemática dos limites entre autodeterminação e autonomia privada, ver Ribeiro (2003, p. 21 e ss.). A diferença marcada pelo autor português pode ser sintetizada na natureza instrumental da conexão entre os dois conceitos: "a autonomia privada relaciona-se com a autodeterminação como um meio para o seu fim (um dos seus fins) [...] a autonomia privada não é uma componente da autodeterminação, mas apenas uma técnica de criação jurídica ajustada à autodeterminação." (RIBEIRO, 2003, p. 30).

36 O sistema constitucional pressupõe a autonomia privada a partir de uma série de comandos que devem ser compreendidos em conjunto, entre eles os incisos do art. $5^{\circ}$, acima citados, que tratam da liberdade geral, liberdade profissional, liberdade de associação, e que garantem eficácia ao ato jurídico perfeito e, portanto, a eficácia obrigatória e a irretratabilidade dos negócios jurídicos. Há opinião contrária, como por exemplo, a de Ana Prata (1982, p. 78), que afirma não se poder considerar a autonomia privada como manifestação da liberdade individual, porque isso representa "erigir em ordem natural aquilo que é ordem económica históricamente referenciada." O equívoco da afirmação de Ana Prata é a confusão entre o Direito Fundamental da liberdade e um pressuposto Direito Natural à liberdade, que não estão em debate na atualidad 
Quanto a esse ponto, a Lei instituidora do desconto em folha e da impossibilidade de seu cancelamento viola o substantial due processo flaw, pois a norma tem caráter contraditório e teratológico, não obedecendo à máxima da proporcionalidade no ponto em que atribui a possibilidade de autopagamento e de permissão que o credor fique com o objeto da garantia.

Embora não se possa negar a legitimidade do legislador, este não pode ser arbitrário a ponto de distorcer a tradição e a história de proteção dos devedores contra os abusos e o excesso de poder constituído por atos voluntários, pois quando o legislador tenta mudar a tradição com subversão da lógica de proteção dos direitos fundamentais, subvertendo a lógica inerente à própria cultura e a todo o conhecimento acumulado, inclusive invariantes axiológicas que estão por detrás da construção do conceito de autonomia privada, há evidente violação do substancial due processo flaw, como já decidiu o Supremo Tribunal Federal, na esteira da tradição democrática trilhada pela Suprema Corte Norte Americana.

Para finalizar, vale registrar a proposição de Canaris (2006, p. 217), que sintetiza: "o legislador também está vinculado sem mediações aos direitos fundamentais no campo do Direito Privado. Por isso ele não pode restringi-los desmedidamente. Quando o faz, a regulamentação em espécie é inconstitucional." Assim, o legislador pode modificar conceitos, mas não pode fazê-lo ao arrepio do texto constitucional, dos seus valores e da lógica do sistema em que está inserido.

\section{Referências}

ALEXY, Robert. Teoria dos direitos fundamentais. São Paulo: Malheiros, 2008.

ALMEIDA COSTA, Mário Júlio. Direito das obrigações. 12. ed. Coimbra: Almedina, 2009.

ARENDT, Hannah. A condição humana. Rio de Janeiro: Forense Universitária; Rio de Janeiro: Salamandra; São Paulo: EDUSP, 1981. 
ASCARELLI, Tullio. Panorama do direito comercial. São Paulo: Saraiva, 1947.

AZEVEDO, Antônio Junqueira de. Negócio jurídico: existência, validade e eficácia. São Paulo: Saraiva, 2002.

BETTI, Emilio. Teoria general de las obligaciones. Madrid: Revista de Derecho Privado, 1969. t. I.

BRANCO, Gerson Luiz Carlos. Função social dos contratos: interpretação à luz do Código Civil. São Paulo: Saraiva, 2009.

BRANCO, Gerson Luiz Carlos; MARTINS-COSTA, Judith. Diretrizes teóricas do Código Civil. São Paulo: Saraiva, 2002.

BROWNSWORD, Roger. Contract law: themes for the twenty-first century. Oxford: Oxford University Press, 2006.

CANARIS, Claus-Wilhelm. A influência dos direitos fundamentais sobre o direito privado na Alemanha. In: SARLET, Ingo Wolfgang (Org.). Constituição, direitos fundamentais e direito privado. 2. ed. rev. e ampl. Porto Alegre: Livraria do Advogado, 2006. p. 205-220.

CARDOSO, Eliana. Implicit and explicit taxation of financial intermediaries in Brazil: the effect of reserve requirements on bank spreads. In: WORLD BANK CONFERENCE ON TAXATION OF FINANCIAL INTERMEDIARIES, Georgetown, 2002. Anais... Disponível em: <http:// siteresources.worldbank.org/INTFR/Resources/Cardoso_Brazil.pdf> Acesso em: 21 nov. 2006.

CORDEIRO, Antonio Menezes. Direito das obrigações. Lisboa: EAAFDL, 1980.

DANTAS, F. C. de San Tiago. Problemas de direito positivo. Rio de Janeiro: Forense, 1953.

GALGANO, Francesco. Diritto civile e commerciale. Volume secondo: Le obbligazioni e i Contratti. 3. ed. Padova: CEDAM, 1999. Tomo primo.

GUERRA, Sidney; EMERIQUE, Lilian Márcia Balmant. O princípio da dignidade da pessoa humana e o mínimo existencial. Revista da 
Faculdade de Direito de Campos, Rio de Janeiro, v. 7, n. 9, p. 379397, dez. 2006.

HESPANHA, António Manuel. Panorama histórico da cultura jurídica europeia. Lisboa: Europa-América, 1997.

LARENZ, Karl. Derecho de obligaciones. Madrid: Revista de Derecho Privado, 1959. t. I.

LEITÃO, Luís Manuel Teles de Menezes. Garantias das obrigações. 2. ed. Coimbra: Almedina, 2008.

MARX, Karl. O capital: crítica da economia política: livro 3. Tradução de Reginaldo Santana. Rio de Janeiro: Civilização Brasileira, 1993. v. 6.

MARTINS-COSTA, Judith. Negócio jurídico de assunção de dívida: algumas notas. Revista Jurídica In-Pactum, Recife, v. 7, p. 158-170, 2011.

. O regime dos juros no novo direito privado brasileiro. Revista da AJURIS, Porto Alegre, v. 105, p.237-264, mar. 2007.

MIRANDA, Jorge. Escritos vários sobre direitos fundamentais. São João do Estoril: Principia, 2006.

MIRANDA, Pontes de. Tratado de direito privado. Rio de Janeiro: Borsoi, 1954. t. XX.

OLIVEIRA, Jorge Rubem Folena de. Alei (n.10.820/2003) do empréstimo consignado e a sua inconstitucionalidade. Revista de Informação Legislativa, Brasília, DF, ano 43, n. 172, p.225-228, out./dez. 2006.

OLIVEIRA, Maria Rosynete. Devido processo legal. Porto Alegre: Fabris, 1999.

OPPO, Giorgio. Obbligazioni e negozio giuridico. Padova: CEDAM, 1999. v. 3.

PERLINGIERI, Pietro. Perfis do direito civil: introdução ao direito civil constitucional. 2. ed. Tradução de Maria Cristina de Cicco. Rio de Janeiro: Renovar, 2002. 
PRATA, Ana. A tutela constitucional da autonomia privada. Coimbra: Almedina, 1982.

REALE, Miguel. Fontes e modelos do direito: para um novo paradigma hermenêutico. São Paulo: Saraiva, 1999.

RIBEIRO, Joaquim de Sousa. O problema do contrato as cláusulas contratuais gerais e o princípio da liberdade contratual. Coimbra: Almedina, 2003.

THE HONOURABLE Lord Reed. The constitutionalisation of private law: Scotland. Electronic Journal of comparative Law, Netherland, v. 5.2, may. 2001. Disponível em: <http://www.ejcl.org/52/art52-4.html>. Acesso em: 8 abr. 2012.

THEODORO JÚNIOR, Humberto. A cédula de crédito bancário como título executivo extrajudicial no direito brasileiro. Disponível em: <http://www.abdpc.org.br/artigos/artigo48.htm>. Acesso em: 22 maio 2013.

SMITS, Jan M. Private law and fundamental rights: a sceptical view. In: BARKHUYSEN, Tom; LINDENBERGH, Siewert (Ed.). Constitutionalisation of private law. Leiden: Brill Academic; Boston: Martinus Nijhoff Publishers, 2006. p. 9-22.

VARELA, João de Matos Antunes. Das obrigações em geral. 10. ed. Coimbra: Almedina, 2000.

Data de recebimento: $11 / 04 / 13$

Data de aprovação: 17/12/13 